\title{
Evaluation of the Allelopathic Potential of Fifteen Common Malaysian Weeds
}

\author{
(Penilaian Potensi Alelopati ke atas Lima Belas Rumpai Biasa di Malaysia)
}

\author{
NURUL AIN, M.B., NORNASUHA, Y.\& ISMAIL, B.S.*
}

ABSTRACT

The use of allelopathy concept in weed management has received attentions to minimize extensively the reliance on herbicide applications on the agriculture industry in Malaysia. A laboratory study was conducted to evaluate the allelopathic potential of 15 Malaysian common weed species of different morphological characteristics (broadleaves, sedges and grasses). They were screened using the Sandwich method (from leaf litter leachate) and the Dish pack method (for testing the presence and content of volatile compounds in weeds). Among the 15 weed species tested, the leaf litter leachate of Centrosema pubescens was observed to be the most sensitive plant material inhibiting the growth of lettuce radicle (84\%) and hypocotyl (55\%) in the Sandwich bioassay compared to the control. This was followed by Asystasia gangentica (81\%) and Cynodon dactylon (80\%) inhibiting the lettuce radicle growth. In the Dish pack bioassay, Rhynchelytrum repens demonstrated maximum inhibition on the radicle and hypocotyl elongations by $44 \%$ and $29 \%$, respectively, (over control) at $41 \mathrm{~mm}$ distance from the source well. Meanwhile, at the same distance, Cynodon dactylon was observed to have the least inhibitory effect on lettuce radicle growth by $12 \%$. The results presented can be utilized as benchmark information for further research on the identification and isolation of allelochemicals for weed control strategies.

Keywords: Allelochemical; allelopathy; dish pack method; sandwich method

\section{ABSTRAK}

Penggunaan konsep alelopati dalam pengurusan rumpai telah mendapat perhatian untuk meminimumkan kebergantungan secara meluas terhadap penggunaan racun rumpai ke atas ladang pertanian di Malaysia. Kajian makmal telah dijalankan untuk mengenal pasti potensi alelopati terhadap 15 spesies rumpai biasa di Malaysia yang berbeza secara fizikal luarannya (daun lebar, rusiga dan rumput) dan ia disaring menggunakan kaedah Sandwich (daripada sarap daun) dan kaedah Dish pack (untuk menguji kehadiran dan kandungan bahan meruap dalam rumpai). Daripada 15 spesies rumpai yang diuji, sarap daun Centrosema pubescens diperhati sebagai bahan tumbuhan yang paling sensitif dalam merencatkan pertumbuhan akar selada (84\%) dan pucuk selada (55\%) dalam bioasai Sandwich berbanding kawalan, diikuti dengan Asystasia gangentica (81\%) dan Cynodon dactylon (80\%) yang merencatkan akar selada. Dalam bioasai Dish pack, Rhynchelytrum repens menunjukkan perencatan maksimum ke atas pemanjangan akar dan pucuk masingmasing sebanyak 44\% dan 29\% (berbanding kawalan) pada jarak 41 mm dari lubang punca tumbuhan penderma. Walau bagaimanapun, pada jarak yang sama, Cynodon dactylon diperhatikan mengalami kesan perencatan paling sedikit terhadap pertumbuhan akar sebanyak $12 \%$. Keputusan yang dibentangkan dapat digunakan sebagai maklumat penanda aras untuk kajian selanjutnya ke atas pengenalpastian dan pengasingan alelokimia terhadap strategi pengawalan rumpai.

Kata kunci: Alelokimia; alelopati; kaedah dish pack; kaedah sandwich

\section{INTRODUCTION}

Malaysia has been classified as one of the top countries rich in biodiversity. There are 15,000 plant species of which more than 100 weed species in the Malaysian agroecosystems are invasive (Baki 2004). The warm tropical climate coupled with adequate rainfall throughout the year is very conducive to the luxuriant growth of weeds. Weed has been found to colonize and invade new farming areas, intensive agricultural sites and abandoned farmlands (Baki 2004). Weed infestation is one of the major constraints of the plantation industry in Malaysia since weeds compete with the cultivated crops for available space, nutrients and moisture. Thus, weeds reduce productivity and lower the quality of the produce (Sahid \& Chan 2000). A weed can be defined as a plant growing in a place where it is not desired and weeds compete for the limited space and available resources with the crop plant (Altieri 1988). Depending on their morphological characteristics weeds are classified into four groups namely grasses, sedges, broadleaved weeds and ferns (Barnes \& Chan 1990).

Weeds are the major component that interferes in the oil palm production system. In Malaysia, 60 to 70 weed species have been reported to be growing under young oil palms, and of these 20 to 30 species are found under the older trees (Mohamad et al. 2010). Weeds also invade estates and rice cultivation areas. The use 
of herbicides to control weeds is a common practice and chemical herbicides are used in most extensively agricultural plantations of Malaysia. The annual global cost of herbicides in rice cultivation system is expected to reach US $\$ 3$ billion by the year 2025 (Zhang et al. 2004). The constant use of chemical herbicides also leads to an increased risk of herbicide-resistance, environmental pollution, unsafe agricultural products, and negative effects on human health (Vyvyan 2002). Thus, there has been an increased effort globally to replace synthetic herbicides with other alternatives to minimize reliance on herbicides. The use of the allelopathy concept in weed management has recently received much attention. It can be carried out by utilizing the allelopathic interactions either directly or indirectly through the use of allelochemicals as alternative tools for weed control (Dayan et al. 2000; Duke et al. 1996; Kong et al.2002). Allelopathy refers to the direct or indirect chemical effect of one plant on the germination, growth or development of neighbouring plants (Bond 2002). This phenomenon happens when the donor plant releases some allelochemicals into the surrounding environment through volatilization, leachate and root exudates during growth and decomposition of the plant parts (Pimentel et al. 2001). The allelopathic concept itself has been applied particularly in the form of cultural practices and cropping patterns decades ago to suppress weed emergence (De Albuquerque et al. 2010). Allelochemicals are considered valuable in current research methods for the development of new natural herbicides for weed management and control (Saxena et al. 2016). Therefore, the incorporation of invasive weeds with strong allelopathic activity into studies on agro-ecosystems would be an effective weed control strategy (Khan et al. 2010).

Most of the existing research studies on allelopathy have been focused more on specific plants to investigate their allelopathic potential rather than on exploring the allelopathic potential of plants on a broad spectrum. One important matter that needs to be explored is the potential that allelopathic species have on the suppression of weed seed germination and weed seedling emergence (Duke et al. 2002). Several earlier studies focused on selected plant species such as, the potential allelopathic effects of Mikania micrantha on the seed germination and seedling growth of Coix lacryma-jobi (Li \& Jin 2010); the allelopathic inhibition of germination by Alliaria petiolata (Brassicaceae) (Prati \& Bossdorf 2004); the allelopathic effects of Chromolaena odorata (L.) King and Robinson on seed germination and seedlings growth of paddy and banyard grass (Suwal et al. 2010). However, studies on the screening of a broad spectrum of plants for identifying their allelopathic potential are still limited. In view of the importance of discovering the allelopathic potential of several weed species, the present study was undertaken to investigate the allelopathic potential of the leaf litter leachate and volatile compounds from three categories of morphologically different Malaysian weed species on the germination and growth of Lactuca sativa (lettuce), the receptor plant.

\section{MATERIALS AND METHODS}

\section{PLANT MATERIALS}

A total of 15 weed samples namely; Asystasia gangetica, Blumea lacera, Centrosema pubescens, Costus speciosus, Impatiens balsamina, Cyperus kyllingia, Cyperus iria, Cyperus rotundus, Fimbristylis miliacea, Rhynchospora corymbosa, Cynodon dactylon, Eragrostis atrovirens, Panicum maximum, Pennisetum purpureum and Rhynchelytum repens were collected from various localities in Malaysia. They were divided according to their different morphological characteristics namely broadleaves, sedges and grasses. The fresh leaves were put in bags until the time of use. Lactuca sativa (lettuce) seeds were purchased from Takii Seed Co. Ltd, Kyoto, Japan, and used as the bioassay species because of its reliability in germination and its sensitivity to changes.

\section{SANDWICH METHOD}

The sandwich method developed by Fujii et al. (2003), was used to evaluate the allelopathic potential of the leaf litter leachate obtained from the leaves of the selected donor plants. Two different concentrations of the leaf leachate at 10.0 and $50.0 \mathrm{mg}$ were added into separate wells in the 6-well dish (Nalga Nunc. International, Tokyo). Agar (Nacalai Tesque, Kyoto, Japan) was used as the medium for the lettuce seedling growth. About $5.0 \mathrm{~mL}$ of autoclaved agar was added onto the dried leaf samples in each well. Thereafter, another $5.0 \mathrm{~mL}$ of autoclaved agar was poured over as a second layer and allowed to solidify at room temperature. Every treatment was replicated thrice. For the untreated control, $10.0 \mathrm{~mL}$ of agar was poured into each empty well of the multi-dish (containing no plant material). In each well, five L. sativa seeds were placed vertically on the agar and were evenly spaced. The germination and seedling growth (radicle and hypocotyl length) were recorded after incubation in the dark at $20^{\circ} \mathrm{C}$ for four days.

\section{DISH PACK METHOD}

The dish pack experiment was conducted to determine the effect of volatile materials from the leaves of the donor plant on the receptor plant (adopted from Appiah et al. 2015; Fujii et al. 2005). The weed leaf samples were cut approximately to $3.0 \mathrm{~mm}^{2}$ to enhance the release of volatile compounds. Multi-well plastic dishes were used with each well measuring $36.0 \times 18.0 \mathrm{~mm}^{2}$ in size. The source well distances (where plant sample was placed) to the other wells were $41,58,82$ and $92 \mathrm{~mm}^{2}$, respectively, based on the well of the multi-well plastic dish used. The first well (source well) of each multi-well plastic dish was filled with $200.0 \mathrm{mg}$ of the oven-dried weed leaf samples. The remaining five wells had Whatman No. 6 filter paper laid in them. Then, $0.70 \mathrm{~mL}$ of distilled water was pipetted into each of the wells containing the filter paper. Five lettuce seed (the bioassay species) were sown and evenly spaced 
on the filter paper. For the control treatment, there was no plant sample in the source well. Three replicates were done for each leaf weed sample. The multi-well dishes were tightly sealed with cellophane tape to avoid loss of volatile compounds and labeled appropriately. The germination and seedling growth (radicle and hypocotyl length) were recorded after incubation in the dark at $20^{\circ} \mathrm{C}$ for four days.

\section{STATISTICAL ANALYSIS}

The experiment was carried out using a complete randomized design (CRD) with three replications for each type of weed leaf sample. Evaluation of the mean values of the length of the lettuce radicle and hypocotyl were subjected to the analysis of variance, using the software SPSS version 23.0 (Statistical Programme for Social Science) and Microsoft Excel. The mean values of inhibition for each species were compared using the Duncan Multiple Range Test (DMRT) at the 5\% level of significance.

\section{RESULTS AND DISCUSSION}

\section{ALLELOPATHIC EFFECTS OF THE LEAF LEACHATE OF COMMON MALAYSIAN WEED SPECIES (AS DETERMINED BY THE SANDWICH METHOD)}

The sandwich method presented benchmark information on the type of chemicals involved in the allelopathy phenomenon in nature by the leaching off mechanism (Shinwari \& Fujii 2013). The effects of the radicle and hypocotyl length of the lettuce seedlings (bioassay species) from two different concentrations of the dried leaves of 15 weed species are shown in Tables 1 and 2. It can be seen that the radicle and hypocotyl length of the lettuce seedlings were reduced significantly $(p>0.05)$ by the leaf leachate of the different donor species. The leaf leachate of the different weed species inhibited the radicle and hypocotyl elongation of the lettuce seedlings.

Based on the mean percentage inhibition results obtained, it was observed that, both radicle and hypocotyl growth of lettuce were affected by the leaf litter leachate of the different weed species ranging from 53-85\% and $10-55 \%$, respectively. The radicle elongation is the most sensitive growth variable measured in allelopathic studies. Inhibition of lettuce radicle elongation ranging from 80$89 \%$ occurred in three species (Centrosema pubescens, Asystasia gangetica and Cynodon dactylon), 70-79\% in two species (Rhynchelytrum repens and Fimbristylis miliacea), 60-69\% in six species (Panicum maximum, Pennisetum purpureum, Impatiens balsamina, Eragrostis atrovirens, Costus speciosus and Blumea lacera) and 50$59 \%$ in four species (Cyperus rotundus, Cyperus kyllingia, Cyperus iria and Rhynchospora corymbosa).

The inhibitory effect on radicle elongation by each weed species was more than $50 \%$ whereby the inhibitory effect on the hypocotyl growth was less than $50 \%$, with the exception of $C$.pubescens $(55.03 \%)$. Four species namely, $F$. miliacea, A. gangetica, $R$. repens and E. atrovirens demonstrated lettuce inhibition in the range of $40-49 \%$. The species $C$. dactylon, $C$. speciosus, I. balsamina and $P$. purpureum demonstrated lettuce hypocotyl inhibition in the range of 30-39\%. The species C. iria, P. maximum, $R$. corymbosa and C. kyllingia inhibited lettuce hypocotyl growth in the range of $20-29 \%$ whereas, $C$. rotundus $(11.48 \%)$ and $B$. lacera $(10.97 \%)$ showed the least inhibitory effect on the lettuce hypocotyl growth.

TABLE 1. Allelopathic effects (growth inhibition) of different concentrations of the weed leaf litter leachate (\% control) on lettuce radicle growth as determined by the sandwich method

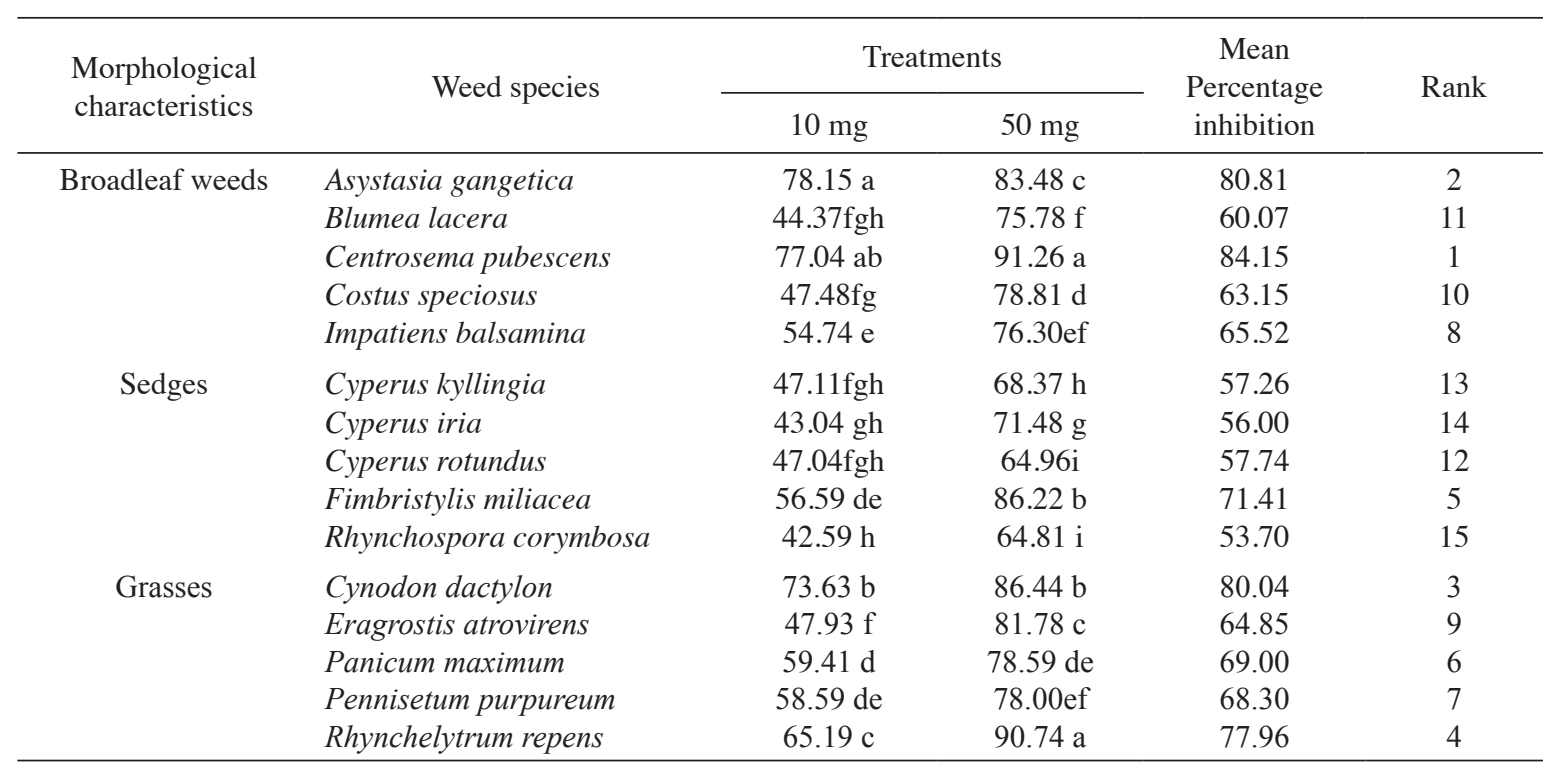

Means values followed by the same alphabet within each column are not significant at $p<0.05$ according to Duncan's multiple range test

Values given in the table are inhibition percentage over that of the control

*Plant were ranked in order of their inhibitory activity 
TABLE 2. Allelopathic effects (growth inhibition) of different concentrations of the weed leaf litter leachate (\% control) on lettuce hypocotyl growth as determined by the sandwich method

\begin{tabular}{|c|c|c|c|c|c|}
\hline \multirow{2}{*}{$\begin{array}{l}\text { Morphology } \\
\text { characteristic }\end{array}$} & \multirow[b]{2}{*}{ Weed species } & \multicolumn{2}{|c|}{ Treatments } & \multirow{2}{*}{$\begin{array}{c}\text { Mean } \\
\text { Percentage } \\
\text { inhibition }\end{array}$} & \multirow[b]{2}{*}{ Rank } \\
\hline & & $10 \mathrm{mg}$ & $50 \mathrm{mg}$ & & \\
\hline \multirow[t]{5}{*}{ Broadleaf weeds } & Asystasia gangetica & $39.74 \mathrm{a}$ & 47.74 cde & 43.74 & 3 \\
\hline & Blumea lacera & $-9.55 h$ & $31.48 \mathrm{fg}$ & 10.97 & 15 \\
\hline & Centrosema pubescens & $39.87 \mathrm{a}$ & $70.19 \mathrm{a}$ & 55.03 & 1 \\
\hline & Costus speciosus & $25.03 \mathrm{~cd}$ & $49.03 \mathrm{~cd}$ & 37.03 & 7 \\
\hline & Impatiens balsamina & $26.84 \mathrm{bcd}$ & $41.03 \mathrm{def}$ & 33.94 & 8 \\
\hline \multirow[t]{5}{*}{ Sedges } & Cyperus kyllingia & $14.19 \mathrm{ef}$ & $32.39 \mathrm{fg}$ & 23.29 & 13 \\
\hline & Cyperus iria & 21.68 cde & $35.61 \mathrm{fg}$ & 28.65 & 10 \\
\hline & Cyperus rotundus & $9.55 \mathrm{f}$ & $13.42 \mathrm{~h}$ & 11.48 & 14 \\
\hline & Fimbristylis miliacea & $35.48 \mathrm{ab}$ & $59.35 \mathrm{~b}$ & 47.42 & 2 \\
\hline & Rhynchospora corymbosa & 18.45 def & $29.29 \mathrm{~g}$ & 23.87 & 12 \\
\hline \multirow[t]{5}{*}{ Grasses } & Cynodon dactylon & $29.16 \mathrm{bc}$ & $49.03 \mathrm{~cd}$ & 39.10 & 6 \\
\hline & Eragrostis atrovirens & $25.81 \mathrm{~cd}$ & $56.77 \mathrm{bc}$ & 41.29 & 5 \\
\hline & Panicum maximum & 20.52 cde & $32.00 \mathrm{fg}$ & 26.26 & 11 \\
\hline & Pennisetum purpureum & $21.55 \mathrm{cde}$ & 38.84 efg & 30.19 & 9 \\
\hline & Rhynchelytrum repens & $24.26 \mathrm{cde}$ & $61.03 \mathrm{~b}$ & 42.65 & 4 \\
\hline
\end{tabular}

Means values followed by the same alphabet within each column are not significant at $p<0.05$ according to Duncan's multiple range test Values given in the table are inhibition percentage over that of the control

*Plants were ranked in order of their inhibitory activity

The results showed that, the application of the leaf leachate of plant materials from each weed species significantly increased the level of inhibition of the radicle and hypocotyl elongation of the bioassay plants as the concentration of leaf leachate used increased from 10 to $50 \mathrm{mg}$ (compared to control). The allelopathic effect in terms of radicle and hypocotyl elongation appeared to be concentration dependent. The laboratory experiment showed that, the percentage of inhibition on lettuce growth was dependent on the concentration of plant leaf leachate applied. For both concentration of 10 and $50 \mathrm{mg}$ of the oven-dried leaf treatments, the lettuce radicle growth was suppressed more severely than the hypocotyl growth. The radicle elongation is the most sensitive growth variable and it is measured in allelopathic studies since the effect on radicle elongation is more dependent on the physiological characteristics (Haugland \& Brandsaeter 1996).

In terms of lettuce growth suppression, it can be highlighted that $C$. pubescens ranked top among the 15 weed species tested. $C$. pubescens, a broadleaved weed which caused $84 \%$ percentage inhibition, had the strongest allelopathic potential among the species evaluated using the sandwich method. The leaf leachate from C.pubescens had the strongest inhibitory effect in reducing the lettuce radicle and hypocotyl growth compared to the leachate of the other weed species evaluated. It was observed that, lettuce seedlings grown with 10 and $50 \mathrm{mg}$ leaf litter leachate of $C$. pubescens recorded remarkable reduction in radicle length of more than $70 \%$ and $90 \%$, respectively. The suppression of the hypocotyl growth of more than $35 \%$ and $70 \%$ was obtained when treated with 10 and 50 mg concentration of the leaf litter leachate, respectively.
Centrosema pubescens also known as Centro or butterfly pea which belongs to the family Fabaceae originated from Central and South America. It is abundant in humid tropical environments. C. pubescens is a vigorous, trailing, twining and climbing perennial herbaceous species with trifoliate leaves and which is fairly drought tolerant (Skerman et al. 1988). C. pubescens has been used as a forage crops and is a great source of protein to grazing cattle (Offor \& Wariboko 2013). During the nineteenth century, $C$. pubescens was introduced to Malaysia and Indonesia as a cover crop. According to Offor and Wariboko (2013), the combination of grass and C. pubescens (a legume) has better suppressive effect on weeds by creating a dense ground cover and spreading naturally to cover a large surface area. $C$. pubescens is grown as a cover crop because it is able to suppress weeds biologically as it has a twining vigorous growth habit. Leguminous cover crop species commonly used in Malaysia are Pueraria javanica, Centrosema pubescens, Calopogonium mucunoides, Calopogonium caeruleum and Mucuna bracteata (Mathews \& Saw 2007).

The study showed that $C$. pubescens exhibited the strongest allelopathic potential in inhibiting the growth of the radicle and hypocotyl of the lettuce plant (bioassay plant). The bioassay seedlings were in stress due to the application of the leaf leachate of $C$. pubescens. The factor that influences the allelopathic activity of a plant is the chemical content or allelochemicals that are present is the donor species. Secondary plant metabolites or allelochemicals suppressed seed germination and seedling emergence, therefore, these are some of the compounds that may be useful directly as herbicides or as templates for herbicide development. $C$. pubescens has 
been reported to be rich in isoflavone glycoside such as pubescidin, sitosterol, stigmasterol and sitosterol 3-O- $\beta$ D-glucopyranoside from HPLC analysis (Tostes et al. 1997). Isoflavone is always present in the Fabaceae family. Isoflavone is a secondary metabolite that affects plant physiology, biochemistry and ecological functions (Taylor \& Grotewold 2005). Therefore, these allelochemicals in $C$. pubescens might have caused growth reduction in lettuce.

ALLELOPATHIC EFFECTS OF THE LEAF LEACHATE OF COMMON MALAYSIAN WEED SPECIES (AS DETERMINED BY THE DISH PACK METHOD)

The dish pack method presents the route of action for evaporation of the volatile allelochemicals from the leaves of plant species. This experiment gives crucial benchmark information for analyzing volatile chemical compounds released through allelopathy in nature. Tables 3 and 4 represent the growth inhibition of the radicle and hypocotyl of the lettuce seedling (bioassay plant) at different positions and distances from the source well. The position and distances were based on the distance between test plant and lettuce seeds in the Multi-well dish plastic in order to check the intensity of volatile compounds activities in noncontact system (Fujii et al. 2005). About 15 plant species of different morphological characteristics were tested and from different plant families. The dish pack experiment showed that, the radicle and hypocotyl elongation of the lettuce seedlings were significantly reduced by the volatile allelochemicals released from the different donor weed species. The dried leaf of the 15 weed species inhibited the radicle and hypocotyl elongation of the lettuce seedlings compared to that of the corresponding control.
Based on the dish pack experiment, the observed rate of inhibition of the lettuce radicle growth (Table 3) ranged from 10-40\% after treatment with 15 common Malaysian weed species of different morphological characteristics. Radicle elongation is the most sensitive growth variable measured in allelopathic evaluations (Sairah et al. 2014). The allelopathic effects on lettuce growth in terms of radicle elongation depended on the concentration of volatile chemicals from the donor species. The weed, $R$. repens was observed to produce the strongest inhibitory effect on the lettuce radicle growth with percentage inhibition up to $39 \%$. Three other species (C. pubescens, A. gangetica and $C$. speciosus) caused radicle growth reduction in the range of $20-30 \%$. Growth inhibition between 10-20\% was observed after treatment with seven weed species (C.rotundus, E. atrovirens, I. balsamina, $R$. corymbosa, B. lacera, C. kyllingia and F. miliacea). The species $C$.iria,P.maximum, P.purpureum and C.dactylon suppressed lettuce radicle elongation by $10-15 \%$.

Table 4 represents the percentage inhibition on lettuce hypocotyl growth at four different distance positions from the source well (where weed samples were placed). Based on the results obtained, the mean percentage inhibition occurred on each weed sample was less than $30 \%$. An inhibition of lettuce hypocotyl elongation using the dish pack method was as follows: Inhibition of 20-30\% occurred in three species ( $R$. repens, A. gangetica and $E$. atrovirens); inhibition of 15-20\% occurred in three species (C. rotundus, $P$. maximum and $C$. kyllingia); inhibition of $10-15 \%$ occurred in five species (R. corymbosa, $C$. speciosus, F. miliacea, $C$.pubescens and $C$. iria) and inhibition of 1-10\% occurred in four species (B. lacera, $I$. balsamina, $C$. dactylon and $P$. purpureum).

TABLE 3. Allelopathic effects (growth inhibition) of different distances of plant volatile compounds ( $\%$ control) on lettuce radicle as determined by the dish pack method

\begin{tabular}{|c|c|c|c|c|c|c|c|}
\hline \multirow{2}{*}{$\begin{array}{l}\text { Morphological } \\
\text { characteristics }\end{array}$} & \multirow{2}{*}{ Weed species } & \multicolumn{4}{|c|}{ Distances from the source well } & \multirow{2}{*}{$\begin{array}{c}\text { Mean } \\
\text { percentage } \\
\text { of inhibition }\end{array}$} & \multirow{2}{*}{ Rank } \\
\hline & & $41 \mathrm{~mm}$ & $58 \mathrm{~mm}$ & $82 \mathrm{~mm}$ & $92 \mathrm{~mm}$ & & \\
\hline \multirow{5}{*}{$\begin{array}{l}\text { Broadleaf } \\
\text { weeds }\end{array}$} & Asystasia gangetica & $35.55 \mathrm{ab}$ & $15.42 \mathrm{bcd}$ & 17.58 bcde & $30.96 \mathrm{ab}$ & 24.83 & 3 \\
\hline & Blumea lacera & $29.92 \mathrm{bc}$ & $17.33 \mathrm{bcd}$ & 13.39 cde & 10.46 def & 17.77 & 9 \\
\hline & Centrosema pubescens & $25.52 \mathrm{~cd}$ & $23.43 \mathrm{~b}$ & $26.36 \mathrm{ab}$ & $32.63 \mathrm{ab}$ & 26.99 & 2 \\
\hline & Costus speciosus & 21.34 dce & $15.48 \mathrm{bcd}$ & $34.73 \mathrm{a}$ & 15.48 cde & 21.76 & 4 \\
\hline & Impatiens balsamina & $24.48 \mathrm{~cd}$ & $15.90 \mathrm{bcd}$ & $17.99 \mathrm{bcd}$ & 20.50 cde & 19.72 & 7 \\
\hline \multirow[t]{5}{*}{ Sedges } & Cyperus kyllingia & $23.64 \mathrm{~cd}$ & $17.16 \mathrm{bcd}$ & 15.06 bcde & $10.46 \mathrm{def}$ & 16.58 & 10 \\
\hline & Cyperus iria & $20.08 \mathrm{de}$ & $18.41 \mathrm{bc}$ & 13.81 cde & 6.69 ef & 14.75 & 12 \\
\hline & Cyperus rotundus & $20.50 \mathrm{de}$ & $17.99 \mathrm{bc}$ & 14.64 bcde & $26.36 \mathrm{abc}$ & 19.87 & 5 \\
\hline & Fimbristylis miliacea & $17.99 \mathrm{de}$ & $12.97 \mathrm{bcd}$ & 15.06 bcde & 15.48 cde & 15.38 & 11 \\
\hline & Rhynchospora corymbosa & $18.41 \mathrm{de}$ & $19.66 \mathrm{bc}$ & $25.52 \mathrm{abc}$ & $10.04 \mathrm{def}$ & 18.41 & 8 \\
\hline \multirow[t]{5}{*}{ Grasses } & Cynodon dactylon & $14.23 \mathrm{e}$ & $9.62 \mathrm{~cd}$ & $5.02 \mathrm{ef}$ & 17.16 cde & 11.51 & 15 \\
\hline & Eragrostis atrovirens & 23.43 & $19.66 \mathrm{bc}$ & $13.39 \mathrm{cde}$ & $22.59 \mathrm{abcd}$ & 19.77 & 6 \\
\hline & Panicum maximum & 18.62 & $7.11 \mathrm{de}$ & 16.32 bcde & 15.48 cde & 14.38 & 13 \\
\hline & Pennisetum purpureum & $14.23 \mathrm{e}$ & $14.64 \mathrm{bcd}$ & 8.37 def & 15.48 cde & 13.18 & 14 \\
\hline & Rhynchelytrum repens & $42.68 \mathrm{a}$ & $37.24 \mathrm{a}$ & $33.05 \mathrm{a}$ & $34.73 \mathrm{a}$ & 36.92 & 1 \\
\hline
\end{tabular}

Means values followed by the same alphabet within each column are not significant at $p<0.05$ according to Duncan's multiple range test Values given in the table are inhibition percentage compound to that of the control

*Plants were ranked in order of their inhibitory activity 
TABLE 4. Allelopathic effects (growth inhibition) of different distances of plant volatile component (\% control) on lettuce hypocotyl as determined by the dish pack method

\begin{tabular}{|c|c|c|c|c|c|c|c|}
\hline \multirow{2}{*}{$\begin{array}{l}\text { Morphological } \\
\text { characteristics }\end{array}$} & \multirow{2}{*}{ Weed species } & \multicolumn{4}{|c|}{ Distances from the source well } & \multirow{2}{*}{$\begin{array}{c}\text { Mean } \\
\text { percentage } \\
\text { of inhibition }\end{array}$} & \multirow{2}{*}{ Rank } \\
\hline & & $41 \mathrm{~mm}$ & $58 \mathrm{~mm}$ & $82 \mathrm{~mm}$ & $92 \mathrm{~mm}$ & & \\
\hline \multirow{5}{*}{$\begin{array}{l}\text { Broadleaf } \\
\text { weeds }\end{array}$} & Asystasia gangetica & $21.02 \mathrm{ab}$ & $28.53 \mathrm{a}$ & $18.92 \mathrm{abc}$ & $18.92 \mathrm{abc}$ & 21.85 & 2 \\
\hline & Blumea lacera & $12.31 \mathrm{bcdefg}$ & $12.31 \mathrm{bcd}$ & $11.11 \mathrm{bcde}$ & $3.90 \mathrm{ef}$ & 9.91 & 12 \\
\hline & Centrosema pubescens & $12.01 \mathrm{bcdefg}$ & $11.11 \mathrm{bcde}$ & $11.71 \mathrm{bcde}$ & 17.12bcdef & 12.99 & 10 \\
\hline & Costus speciosus & $11.41 \mathrm{cdefg}$ & $11.71 \mathrm{bcde}$ & $18.32 \mathrm{abc}$ & $12.31 \mathrm{bcdef}$ & 13.44 & 8 \\
\hline & Impatiens balsamina & 9.91defg & 9.91cde & $9.31 \mathrm{cdef}$ & 5.71cdef & 8.71 & 13 \\
\hline \multirow[t]{5}{*}{ Sedges } & Cyperus kyllingia & $18.62 \mathrm{bcde}$ & $12.31 \mathrm{bcd}$ & $17.22 \mathrm{abc}$ & 17.72abcd & 16.59 & 6 \\
\hline & Cyperus iria & $8.71 \mathrm{efg}$ & $14.71 \mathrm{bcd}$ & 7.51defg & $11.71 \mathrm{bcdef}$ & 10.66 & 11 \\
\hline & Cyperus rotundus & $15.31 \mathrm{bcdef}$ & $14.71 \mathrm{bcd}$ & $22.52 \mathrm{a}$ & $21.12 \mathrm{ab}$ & 18.17 & 4 \\
\hline & Fimbristylis miliacea & $10.81 \mathrm{cdefg}$ & $12.91 \mathrm{bcd}$ & $18.32 \mathrm{abc}$ & 11.11bcdef & 13.29 & 9 \\
\hline & Rhynchospora corymbosa & $16.52 \mathrm{bcde}$ & $18.32 \mathrm{abc}$ & 14.11abcd & 5.10def & 13.51 & 7 \\
\hline \multirow[t]{5}{*}{ Grasses } & Cynodon dactylon & $7.21 \mathrm{fgh}$ & $9.91 \mathrm{cde}$ & $2.70 \mathrm{efg}$ & $2.70 \mathrm{f}$ & 5.63 & 14 \\
\hline & Eragrostis atrovirens & $19.22 \mathrm{bc}$ & $19.52 \mathrm{abc}$ & $15.91 \mathrm{abcd}$ & $26.73 \mathrm{a}$ & 20.35 & 3 \\
\hline & Panicum maximum & $15.02 \mathrm{bcdefg}$ & $11.11 \mathrm{bcde}$ & $21.32 \mathrm{abc}$ & $20.72 \mathrm{ab}$ & 17.04 & 5 \\
\hline & Pennisetum purpureum & $3.60 \mathrm{gh}$ & 3.90de & $-1.5 \mathrm{~g}$ & $5.71 \mathrm{cdef}$ & 2.93 & 15 \\
\hline & Rhynchelytrum repens & $28.53 \mathrm{a}$ & $22.52 \mathrm{ab}$ & $24.32 \mathrm{a}$ & $23.72 \mathrm{ab}$ & 24.77 & 1 \\
\hline
\end{tabular}

Means values followed by the same alphabet within each column are not significant at $p<0.05$ according to Duncan's multiple range test Values given in the table are inhibition percentage compared to that of the control

*Plants were ranked in order of their inhibitory activity

Among the 15 weed species tested, the volatile allelochemicals from $R$. repens resulted in the strongest inhibitory effects on both the radicle and hypocotyl of the bioassay plant at almost all the four distances from the source well. Therefore, $R$. repens has strong allelopathic potential based on the inhibitory activity on both the radicle and hypocotyl growth of lettuce seedlings. The dish pack method showed that the volatile allelochamicals from $R$. repens species were the highest compared to that of the other weed species tested. This could be due to the rapid inhibiting effects caused by the volatile compounds present in $R$. repens.

Rhynchelytrum repens (Willd.) C.E. Hubb., is a shortlived perennial grass, commonly known as Natal Red-top Grass or by the Malay name, Rumput dawai (Gould 1994). It occurs widespread on dry, open areas and often on sandy soil. It can be easily found in the rubber, oil palm, sugar cane, coconut, tea and cocoa plantations (Padgett 1972). R. repens is a persistent grass that belongs to the family Poaceae and is dispersed efficiently via rhizomes and wind-borne seeds. $R$. repens is widespread in tropical areas and has been consistently observed as an invasive species in pastures, mainly in open areas and at roadsides. Possley and Joyce (2006) observed that, high densities of $R$. repens were associated with a significant reduction in native species diversity due to suppression by $R$. repens.

\section{CONCLUSION}

The results of the study provide insight on the allelopathic potential of some weeds species in Malaysia as well as the presence of allelochemicals in the leaf litter leachate and volatile compound of fifteen Malaysian weed species.
The interaction between the chemicals released from the tested weed species with those of the bioassay species (lettuce) created conditions that were not favourable for its growth. It was observed that, the leaf litter leachate from 15 common weed species produced more positive allelopathic effects than the volatile compounds based on the results from the two methods used.

The ranking of the screened plants, in order of their inhibitory activity, gives information on the allelopathic potential of the weed species. The weed that ranked the highest in the production of inhibiting effects on the lettuce seeds was $C$. pubescens (from the sandwich method). This weed has the potential to be exploited for potent allelochemicals. On the other hand, $R$. repens showed strong allelopathic potential based on the inhibitory activity on the lettuce radicle and hypocotyl growth when dish pack method was used.

Based on the results, it is suggested that $C$. pubescens and $R$. repens have strong potential for development as natural herbicides in weed management. However, further studies need to be carried out in order to determine the content and type of allelochemicals present in $C$. pubescens and $R$. repens. The results presented can be utilized as benchmark information for further research in the development of new environment-friendly natural herbicides.

\section{ACKNOWLEDGEMENTS}

The authors would like to acknowledge their gratitude and thanks to the GUP-2014-087 Grant and Universiti Kebangsaan Malaysia for funding the research. Thanks are also extended to the laboratory assistant and fellow colleagues for their help throughout the research period. 


\section{REFERENCES}

Appiah, K., Li, Z., Zeng, R., Luo, S., Oikawa, Y. \& Fujii, Y. 2015. Determination of allelopathic potentials in plant species in Sino-Japanese floristic region by sandwich method and dish pack method. International Journal of Basic and Applied Sciences 4(4): 381-394.

Altieri, M.A. 1988. The impact, uses and ecological role of weeds in agrosystem. In Weed Management in Agrosystem, edited by Alteieri, M.A. \& Liebman, M. Boca Raton: CRC Press Inc. pp. 2-6.

Baki, B. 2004. Invasive weed species in Malaysia agroecosystem: Species, impacts and management. Malaysian Journal of Science 23: 1-42.

Barnes, D.E. \& Chan, L.G. 1990. Common Weeds of Malaysia. Kuala Lumpur: Ancom Berhad Shah Alam. pp. 1-313.

Bond, W. 2002. Non-chemical weed management. In Weed Management Handbook. 9th ed., edited by Robert, E.L.N. New York: Blackwell Science. pp. 296-297.

Dayan, F.E., Romagni, J.G. \& Duke, S.O. 2000. Investigating the mode of action of natural phytotoxins. Journal of Chemical Ecology 26: 2079-2094.

De Albuquerque, M.B., Santos, R.C., Lima, M.L., Filho, P., Nogueira, R.J.M. \& Camara, C.A.G. 2010. Allelopathy: An alternative tool to improve cropping systems. Journal of Agronomy \& Sustainable Development 31: 279-295.

Duke, S.O., Dayan, F.E., Rimando, A.M., Schrader, K.K., Aliotta, G., Oliva, A. \& Romagni, J.G. 2002. Chemicals from nature for weed management. Weed Science 50: 138-151.

Duke, S.O., Abbas, H.K., Duke, M.V., Lee, H.J., Vaughn, K.C., Amagasa, T. \& Tanaka, T. 1996. Microbial phytotoxins as potential herbicides. Journal of Environmental Science \& Health 31: 427-434.

Fujii, Y., Parves, S., Parves, M., Ohmae, Y. \& Lida, O. 2003. Screening of 239 medicinal plant species for allelopathic activity using the sandwich method. Weed Biology and Management 3(4): 233-241.

Fujii, Y., Minoru, M., Syuntaro, H. \& Hideki, S. 2005. Dish pack method: A new bioassay for volatile allelopathy. Proceeding of the 4th World Congress on Allelopathy. pp. 493-497.

Gould, F. 1994. Rhynchelytrum. In A Revised Handbook to the Flora of Ceylon Dassanayake, edited by Dassanayake, M.D., Fosberg, F.R. \& Clayton, W.D. Volume 8. New Delhi: Amerind Publishing.

Haugland,E. \& Brandsaeter, L.O. 1996. Experiments on bioassay sensitivity in the study of alleloapthy. Journal of Chemical Ecology 22(10): 1845-1859.

Khan, M.A., Kalsoom, U., Khan, M.I., Rahamdad, K. \& Aslam, K. 2010. Screening the allelopathic potential of various weeds. Pakistan Journal Weed Science Resource 17(1): 73-81.

Kong, C., Hu, F. \& Xu, X. 2002. Allelopathic potential and chemical constituents of volatiles from Ageratum conyzoides under stress. Journal of Chemical Ecology 28: 1173-1182.

Li, J. \& Jin, Z. 2010. Potential allelopathic effects of Mikania micrantha on the seed germination and seedling growth of Coix lacryma-jobi. Weed Biology and Management 10: 194-201.

Mathews, J. \& Saw, E.K. 2007. IOI's experiences with establishing Mucuna bracteata on soil derived. In Mucuna bracteata, edited by Goh, K.J. \& Chiu, S.B. Petaling Jaya: Agricultural Crop Trust (ACT).
Mohamad, R.B., Wibawa, W. \& Mohayidin, M.G. 2010. Management of mixed weeds in young oil-palm plantation with selected broad-spectrum herbicides. Pertanika Journal of Tropical Agricultural Science 33(2): 193-203.

Offor, U.S. \& Wariboko, O.N. 2013. Effects of leguminous plants (Centrosema pubescens) as feed additive for growth stimulation on broilers. World Journal of Agricultural Sciences 1(10): 299-302.

Padgett, R.W. 1972. Sixty Weeds of Malaysian Plantations. Kuala Lumpur: Ansul Sdn. Berhad.

Pimentel, D., McNair, S., Janecka, J., Wightman, J., Simmonds, C., O'Connell, C., Wong, E., Russel, L., Zern, J., Aquino, T. \& Tsomondo, T. 2001. Economic and environmental threats of alien plant, animal, and microbe invasions. Agricultural Ecosystem Environment 84: 1-20.

Possley, J. \& Joyce, M. 2006. Competitive effects of the invasive grass Rhynchelytrum repens (Willd.) C.E. Hubb. on pine rock land vegetation. Natural Areas Journal 26(4): 391-395.

Prati, D. \& Bossdorf, O. 2004. Allelopathic inhibition of germination by Alliaria petiolata (Brassicaceae). American Journal of Botany 91: 285-288.

Sahid, I. \& Chan, K.W. 2000. Integrated ground cover management in plantations. In Advances in Oil Palm Research, edited by Basiron, Y., Jalani, B.S. \& Chan, K.W. Kuala Lumpur: Palm Oil Board.

Sairah, S., Muhammad, I.A., Zammurad, I., Ahmed, A.R. \& Muhammad,A. 2014. Root exudates and leaf leachate of 19 medicinal plants of Pakistan exhibit allelopathic potential. Pakistan Journal Botany 46(5): 1693-1701.

Saxena, R., Tomar, R.S. \& Kumar, M. 2016. Allelopathy: A green approach for weed management and crop production. International Journal of Current Research in Bioscience and Plant Biology 3(4): 43-50.

Shinwari, M.B. \& Fujii, Y. 2013. Allelopathic evaluation of shared invasive plants and weeds of Pakistan and Japan for environmental risk assessment. Pakistan Journal of Botany 45(S1): 467-474.

Skerman, P.J., Cameroon, D.G. \& Riveros, F. 1988. Centrosema spp. In Tropical Forage Legumes, edited by Skerman P.J. 2nd ed. Rome Italy: FOA Plant Production and Protection Series. No. 2: 237-257.

Suwal, M.M., Devkota, A. \& Lekhak, H.D. 2010. Allelopathic effects Chromolena ordorata (L.) King \& Robinson on seed germination and seedlings growth of paddy and barnyard grass. Scientific World 8(8): 73-75.

Taylor,L.P.\& Grotewold,E. 2005. Flavonoids as developmental regulators. Current Opinion Plant Biology 8: 317-323.

Tostes, J.B.F., Silva, A.J.R. \& Parente, J.P. 1997. Pubescidin, an isoflavone glycoside from Centrosema pubescens. Phytochemistry 45(5): 1069-1072.

Vyvyan, J.R. 2002. Allelochemicals as leads for new herbicides and agrochemicals. Tetrahedron 58: 1631-1646.

Zhang, W., Webster, E.P., Blouin, D.C. \& Linscombe, S.D. 2004. Differential tolerance of rice (Oryza sativa) varieties to clomazone 1. Weed Technology 18: 73-76.

Nurul Ain, M.B.\& Ismail, B.S.*

School of Environmental and Natural Resource Sciences

Faculty of Science and Technology

Universiti Kebangsaan Malaysia 
43600 UKM Bangi, Selangor Darul Ehsan

Malaysia

Nornasuha, Y.

School of Agricultural Sciences and Biotechnology

Faculty of Bioresources and Food Industry

Universiti Sultan Zainal Abidin, Kampus Besut

22200 Besut, Terengganu Darul Iman

Malaysia
*Corresponding author; email: ismail@ukm.edu.my

Received: 31 August 2016

Accepted: 1 April 2017 